\title{
High-Tech Enterprise Tax Planning
}

\author{
Qiong Zhang \\ Department of Accounting, Jinan University, Guangzhou, China \\ Email: zq1455440638@163.com
}

How to cite this paper: Zhang, Q. (2019) High-Tech Enterprise Tax Planning. American Journal of Industrial and Business Management, 9, 191-203. https://doi.org/10.4236/ajibm.2019.91013

Received: December 14, 2018

Accepted: January 15, 2019

Published: January 18, 2019

Copyright $\odot 2019$ by author(s) and Scientific Research Publishing Inc. This work is licensed under the Creative Commons Attribution International License (CC BY 4.0).

http://creativecommons.org/licenses/by/4.0/

\begin{abstract}
Chinese economy is in transition with expanding domestic demand. The capacity is becoming a new economic normality. High-tech industry as a new force in promoting economic development plays an increasingly important role. Taxation is an important part of corporate financial management, the impact of the economic activity and tax interests of the company, so a reasonable tax planning is conducive to the company's financial management objectives. Many high-tech industries enjoy preferential tax policies, while they are also high input and high output. So it is necessary for high-tech enterprises in tax planning. This paper introduces the theory of tax planning and high-tech industry, and then based on the latest legal summarizes the high-tech enterprises in the value-added tax, business tax, income tax of these three main tax incentives. Combining the features of tax planning concepts and high-tech industry, this paper presents the high-tech industry investment activities, operating activities, financing activities of the three aspects of tax planning strategies. Finally, the paper puts insufficient research from different angles such as policy risk and business risk. In the summary, I pointed out the lack of research presented in this paper and looked forward to the future tax planning.
\end{abstract}

\section{Keywords}

Tax Planning, High-Tech Enterprises, Tax Incentives

\section{Introduction}

\subsection{Background}

After many years of rapid development, Chinese economic growth gradually slowed down. It is in a transitional period now, which needs to develop new growth engines. The boosting domestic demand and the removal of excess capacity are most important in China's economic development. The high-tech enterprises in science and technology become the key to economic development 
due to advances, which promotes the sustainable growth of the GDP, improves the national average income, and achieves economic transformation. Taxation is an important part of the development of enterprises, which directly affects the company's economic activities and after-tax benefits. It is vital to the healthy operation of enterprises, and reasonable tax planning shows great significance to the continuous development of high-tech enterprises. China's current tax planning history is relatively short, and it is at a stage where it has not yet matured, especially for tax planning of high-tech enterprises. The significance and the theoretical contributions of this paper are to make full use of the preferential tax policies owned by high-tech enterprises in the development process, and then to propose reasonable and effective tax planning schemes for high-tech enterprises in tax planning, promoting the development of high-tech enterprises healthily and the continuous growth of Chinese economy.

\subsection{Research Methods and Characteristics}

The main research methods in this paper are case analysis and association analysis. By fully understanding the concepts and methods of tax planning, the corresponding planning methods are proposed in combination with specific cases. The main features of this paper are as follows:

1) The tax planning target of this paper is high-tech enterprises. High-tech enterprises have many tax preferential policies, which not often focus on tax planning. However, under the high risk, tax planning has a strong necessity for high-tech. This paper will give strategic measures for tax planning from the aspects of establishment process of enterprise investment.

2) Multi-angle analysis. The tax planning scheme for high-tech enterprises involves various taxes such as value added tax and income tax. The planning scheme runs through the whole process of high-tech enterprises from establishment to dissolution.

\subsection{Literature Review}

High-tech enterprises take science and technology as their main productive forces, which meet the economic development goals and become the key industries for venture capital investment. Domestic and foreign experts have carried out research on products, management, innovation and other aspects. Tax planning is the key research object. The following is relevant summary of the literature.

As for the concept of tax planning, Tengxiang Tang (1994) wrote the "tax planning". The book summarizes the lessons and effective methods of foreign related companies in tax planning from different aspects of introducing and analyzing tax. The concept of planning in the book is the origin of the follow-up researcher's tax planning research. The tax planning proposed by professor Gedi (2005) refers to the tax planning carried out by taxpayers in the activities of enterprise establishment, operation, investment and financing according to law, 
which aims to reduce taxes and achieve financial goals [1].

As for the current situation of high-tech enterprise tax planning, Shufeng Tong (2012) basing on the perspective of financial management, analyzes the tax planning of related enterprises in the form of cases, and points out the status quo of high-tech enterprises mainly using tax incentives. He proposed that in order to meet the current situation of high-tech enterprises' rapid growth, enterprises should stand on the financial strategy level to carry out tax planning work and gradually improve the tax planning system [2].

As for tax planning program, Zhihan Jiang (2015) analyzed the tax planning scheme of BJGX company in terms of three aspects of value-added tax, income tax and other taxes, and sorted out the problems of enterprises in tax planning from the target design and manpower. The optimization design scheme was proposed in terms of reserves and institutional improvement [3]; Shaowu Bai (2010) proposed a tax planning plan for the establishment, production and operation content and profit distribution mode of high-tech enterprises, with emphasis on the overall tax planning process. [4]; Liduo Cao (2015) researches added tax of the high-tech enterprises on the replacement of business tax with value, and provided tax planning for enterprises provides some countermeasures and suggestions for high-tech [5]; Yunjian Wu (2008) analyzes the necessity, feasibility and particularity of high-tech enterprise tax planning theory, and points out that high-tech enterprises are higher than ordinary enterprises. The characteristics of tax planning risk, focusing on the risk regulation of high-tech enterprise tax planning avoid [6].

Previous articles lack comprehensive summaries and case studies. This paper proposes a high-tech enterprise tax planning plan from three aspects: investment activities, business activities and fund-raising activities. Combined with tax planning theory, high-tech enterprises' special planning strategy and specific cases analyze, I hope to provide corresponding reference for high-tech enterprise tax planning.

\section{High-Tech Enterprise Tax Planning Related Theory}

\subsection{High-Tech Enterprise Concept}

With the advent of the information and Internet era, the driving force of traditional industries for economic growth is weakening, and the output of high-tech industries has become an important part of the gross national product. High-tech enterprises have also become the key development of the state and the government. "High-tech" is mainly reflected in the following areas: enterprise product or service is provided by the core technology with independent intellectual property rights, and the company's products or service within the scope of the provisions of the "high-tech fields supported by the state", the current China's major high-tech enterprises include new materials technology, information technology, aerospace technology, biotechnology, new energy and high-efficiency energy-saving technology, laser technology, automation technology, etc. [7]. In 
terms of employees, technicians with college education or above are required to account for the employees of the year. The proportion of totals exceeds $30 \%$, and the proportion of $\mathrm{R} \& \mathrm{D}$ personnel is over $10 \%$. At the same time, in order to obtain new knowledge of science and technology and improve existing production methods, enterprises should continue research and development activities.

\subsection{Characteristics of High-Tech Enterprises}

The characteristics of high-tech enterprises make them different from traditional industries, and enjoy national policy support, which includes incentives and industry protection. Specifically, there are the following points:

1) Highly intensive. The rate of product upgrading of high-tech enterprises is relatively fast, consumers have a decisive role in the production of products, and market share is growing rapidly. This feature requires innovative products, services and cutting-edge for the production of high technical requirements. In order to achieve technological innovation and product renewal, it is necessary to ensure that knowledge and technology are highly intensive and concentrate on major forces for development.

2) High-input. High-tech enterprises only need a small amount of raw material input in the production process, and the main expenditure items are research and development costs. Technology R \& D requires a lot of time and labor costs, and R \& D tools and technologies have a large demand for capital. In the case of failed research and development, companies need to abandon the previous research results and carry out re-development, so the $\mathrm{R} \& \mathrm{D}$ expenditure is the sunk cost and new cost input of the previous failure study. In order to ensure the innovation of products and the existing market share, the development of high-tech enterprises requires strong funds as supporting to complete technological innovation and improvement, and achieve large-scale production of products [8].

3) High risk. Whether the products developed by the enterprise, have industry competitiveness, the growth potential of market share and the counterfeiting of other companies are the main market risks. The upgrading of products and the changes in user habits make high-tech enterprises face the technical risks of continuous innovation [7].

4) High profitability. When the production technology is mature, the work efficiency is improved, and the product performance is strengthened, the high-tech enterprises have a high profit return rate, and can exert economies of scale to a certain extent. According to the advantages of its technological achievements, when the market share grows rapidly, high-tech enterprises can form monopoly benefits, greatly increase the income of high-tech enterprises, and promote the development of social productivity.

\subsection{Theory of Tax Planning}

Tax planning refers to fully understanding the tax-related economic activities and taxation policies of enterprises under the premise of ensuring legality, ar- 
ranging corporate financial activities from a comprehensive and holistic perspective, controlling and mitigating taxation, and realizing the economic behavior of maximizing after-tax profits. The concept of tax planning is analyzed as follows:

1) The main body of tax planning is the taxpayer. According to the different forms of the enterprise, the person in the partnership enterprise is an individual, and the taxpayer of the company is a corporate legal person. Different tax burden faces different identities of taxpayers, so high-tech enterprises can select the form of corporate tax planning according to their own organization.

2) Legitimacy is the premise of tax planning. Tax planning should respect tax laws and other laws, make full use of tax incentives to rationally arrange economic activities of enterprises, so as to reduce the tax burden of enterprises without violating the law.

3) Fully understanding the tax-related economic activities and taxation policies of enterprises is a necessary for tax planning. Only when tax planning personnel conduct preliminary research and investigations on tax-related economic activities of enterprises, deeply grasp the taxation system and preferential policies involved in economic activities, can we formulate reasonable planning schemes to reduce or avoid tax burdens without violating the legal norms.

4) To achieve the minimum tax burden as a whole, and to maximize profit after tax is the ultimate goal of tax planning. Tax planning is a systematic process that should consider the overall and long-term interests of the company, rather than being limited to the maximization of immediate interests.

\section{The Current Situation of High-Tech Enterprises Tax Planning}

\section{Analysis of the Status Quo of Tax Planning for High-Tech Enterprises}

China's high-tech enterprises mainly exist in the form of small and medium-sized enterprises. The investment scale is small and their capabilities are weak. There are fewer professionals in financial management, and the tax planning for enterprises is in the exploration stage. High-tech enterprises are supported by the state and enjoy preferential tax policies on many types of taxes, providing more strategic plans for tax planning [9]. At the same time, the characteristics of high profit and high investment make the company face greater challenges in the business process, so as to carry out tax planning, reduce expenditures appropriately, and increase the scale of cash flow. The following is a summary of the current status of planning.

1) Tax planning lacks integrity. Tax planning is a systematic process. The ultimate goal is that the overall tax burden of the enterprise is the lowest. This feature requires high-tech enterprises should base on the entire business activities of the company in the planning of tax planning, and consider the long-term development strategy of the company, not only to reduce the current tax burden, 
but to ignore the overall interests of the enterprise. For example, high-tech enterprises in determining the depreciation scheme can choose accelerated depreciation method, depreciation expense by increasing the previous stage. High-tech enterprises invest more in the early stage of establishment, and low profits or may be negative, and the income tax burden is low. Therefore, using the accelerated depreciation method of fixed assets for tax planning will not only reduce the level of tax burden, but will increase the overall tax burden of the enterprise and reduce the value of the enterprise.

2) Tax planning lacks divergence. Tax planning is often carried out after having certain economic capabilities and operating experience, and is mainly limited to the economic activities of the company. Tax planning should run through the existence of the enterprise, and it is the content involved in the whole process from establishment and operation to bankruptcy dissolution. The choice of taxpayer status at the time of establishment, the depreciation plan of fixed assets in the course of business, and the corporate property distribution plan during dissolution are all the focus of tax planning. At the same time, the tax planning of enterprises cannot be limited to the company itself, and should be linked with subsidiaries and companies to achieve tax planning goals [10].

3) Tax planning lacks diversity. At present, the main tax planning scheme for high-tech enterprises is to use tax incentives and accounting treatment methods. But from the perspective of tax planning in other countries, there are other ways to plan for tax planning. The scope of tax planning includes all kinds of taxes such as income tax, turnover tax, resource tax, and property tax. Enterprises should give priority to taxation with large tax flexibility when planning tax planning, and plan together with the overall strategy of the enterprise.

\section{The Strategic Choice of High-Tech Enterprise Tax Planning}

Based on the previous two chapters on tax planning and high-tech theoretical knowledge and a summary of tax planning related policies, this paper will discuss the specific strategic choices of high-tech enterprise tax planning [11]. Tax planning is a business set up, aimed at business, investment, financing and other activities to reduce the tax burden, to help plan and countermeasures financial goals. This paper will discuss the strategic choices of tax planning from three aspects: investment, financing and management of high-tech enterprises. These decisions make tax planning throughout the field of financial decision-making and become an important part of financial management.

\subsection{Tax Planning for Investment Activities of High-Tech Enterprises}

\subsubsection{The Form of Business Organization Tax Planning}

The main key issues faced by enterprises in the initial stage of investment establishment are the different choices of enterprise organization and the choice of taxpayer's identity. Because of the difference in personal income tax and the difference between corporate income tax taxpayers and taxation methods, high-tech enterprises will face different business forms. A reasonable form of enterprise 
organization can enable high-tech enterprises to ease the financial strain caused by high investment in the early stage of establishment.

1) The choice of sole proprietorship, partnership and company

Individual proprietor ships and partnerships do not have legal personality, and the income of the enterprise is only subject to personal income tax. A company-owned enterprise has the status of a legal person, and its natural person investor shall pay personal income tax on the company's dividends or dividends obtained by the company [12]. In addition, the company shall also pay corporate income tax on its net profit, and face a double tax burden. When selecting a form of enterprise organization, a high-tech enterprise should consider the scale, operational capability and investment environment of the enterprise. Although the partnership enterprise does not face double taxation, on the basis of the five-level excess, high-yield high-tech enterprises will face higher income tax rates; high-tech enterprises have high risks, and partners of partnership enterprises unlimited liability, a feature that increases the business risk more instability and high-tech enterprises.

Scholes constructed a model for comparing the after-tax benefits of partnerships or sole proprietorship with companies. The model assumes:

a) Company's pre-tax rate of return is $R_{C}$. The profit before tax of the partnership is $R_{p}$. The company's rate of return after paying corporate income tax and before shareholders' personal income tax is $r_{C}$, then $r_{c}=R_{c}\left(1-t_{c}\right)$. Partnership pre-tax rate of return is $r_{p}=R_{p}\left(1-t_{p}\right)$.

b) Partner pays the tax in $t_{p}$, The annual marginal tax rate. and the accumulated income after the original investment of 1 yuan of the partner after $\mathrm{n}$ years is $\left[1+R_{p}\left(1-t_{p}\right)\right]^{n}$ :

For corporate companies, when the company liquidates or the shareholders sell shares is $t_{c g}$, the capital gains of the shareholders Annual tax consideration the company and its shareholders, the $n$ years later the company $\$ 1$ profit after tax cumulative income:

$$
\left[1+R_{c}\left(1-t_{c}\right)\right]^{n}-t_{c g}\left\{\left[1+R_{c}\left(1-t_{c}\right)\right]^{n}-1\right\}
$$

c) Assume that the after-tax rate of return is $r_{c}^{*}$, When there is no difference between the tax planning of the company and the partnership, then:

$$
r_{c}^{*}=\left[\frac{\left(1+R_{p}\right)^{n}-t_{c g}}{1-t_{c g}}\right]^{\frac{1}{n}}-1
$$

$r_{c}^{*}$ is affected by the following four factors: ordinary tax rate, corporate tax rate, tax payment at the shareholder level, and length of investment. But from a tax perspective, if the post-tax benefits of the company level are greater, choosing the company form is more appropriate than choosing a sole proprietorship or partnership. Tax burden is the result of a variety of factors. It is not only possible to consider one factor [13]. For example, in some regions, a company 
can enjoy preferential tax policies that are not available to partnerships or sole proprietorship.

2) The choice of taxpayer status

In terms of tax law, according to the soundness of enterprise accounting and the sales income of enterprises, enterprises are divided into small-scale taxpayers and general taxpayers. The main difference between the two taxpayers is the payment and deduction of value-added tax. The taxpayer of VAT can issue and obtain special VAT invoices, and the input tax amount of the invoices obtained by them will be deducted from the output tax. The common tax rates are $17 \%$, $13 \%, 11 \%, 6 \%$. The deduction of input tax is levied at a rate of $3 \%$.

High-tech enterprises spend less on raw material procurement, and the input tax that can be used for deduction is lower, while the products of high-tech enterprises have higher value-added rates. In the face of the premise in this case, if you choose the general taxpayer identity, you will face with a relatively high VAT rate, so choosing low tax rate of $3 \%$ can reduce the burden of high-tech enterprises.

\subsubsection{Tax Planning for the Establishment of the Company}

1) Choice of investment location

There are regional differences in China's tax incentives for various high-tech enterprises. Different regions enjoy different tax incentives. Enterprises can set up tax registrations according to their own and market conditions when setting up their registration sites. Shenzhen, Zhuhai, Shantou and Pudong Shanghai New Areas have many tax incentives for high-tech enterprises. High-tech development zones and special economic zones are conducive to high-tech enterprises to achieve better development and optimal tax planning. Registration place [14].

2) Handling of qualifications

When a high-tech enterprise is established, it shall apply for accreditation as soon as possible. Because high-tech enterprises enjoy the tax preferential policies must be approved by the local competent tax authorities, the basis for approval is the various types of qualification certification documents submitted by enterprises. The primary link in tax planning is to obtain qualifications such as high-tech enterprise certificates and software enterprise certificates.

\subsection{Tax Planning for the Operation Activities of High-Tech Enterprises}

In the process of production and operation, enterprises involve many taxation projects. Tax planning runs through the whole process of production and operation of enterprises. Tax planning is necessary for enterprises from beginning to end. High-tech enterprises can not only carry out tax planning through the choice of inventory calculation methods, but also can make tax planning through the selection of national asset depreciation methods, the regulation of pre-tax profits, and the transaction methods of related parties. 


\subsubsection{Fixed Assets Depreciation Tax Planning}

The new technology industry relies more on advanced technology equipment and advanced scientific theories, such as the new materials technology industry, the aerospace industry, the new energy industry, and intelligent machine manufacturing. High-tech enterprises invest more in fixed assets. The investment costs of fixed assets should be costed first of all, and then converted into depreciation credit sales income in the subsequent fiscal year, reducing corporate income tax expenses. The different choices of depreciation methods for fixed assets and the different choices of depreciation years have become an important method for high-tech enterprises to carry out reasonable and effective tax planning. In the early stage of establishment of high-tech enterprises, the company's research and development expenditures and various inputs are relatively high, and the profit level is low. It is suitable to adopt the average age method, so that the annual profit is balanced [15]. When the business is stable, accelerated depreciation method will be selected to push early profits late for put off tax time.

\subsubsection{R \& D Expenses Tax Planning}

High-tech enterprises are researching and innovating constantly. Their investment in intangible assets is relatively high. The company's research and development expenditure can be recognized as intangible assets, which will be amortized in the future business year. It will be deducted from the income of the future year. It can also be selected as the current expenses to directly offset the current profits. When making a choice, an enterprise should consider the tax policy enjoyed by the enterprise to confirm it.

\subsubsection{Distribution of Profits Tax Planning}

Shareholders' wealth mainly comes from the dividends of corporate after-tax profits and dividend income. Formulating an appropriate dividend distribution policy and reducing the tax burden of shareholders' income has become the content of tax planning and financial management. The following is a discussion of the tax planning scheme in terms of the form of dividend distribution, the time and amount of dividend distribution.

1) Tax planning in the form of dividend distribution

Cash dividend, stock dividend and transfer capital are three main forms of dividend distribution. Different dividend distribution forms have different tax payment methods, which provides space for tax planning. Dividend distribution methods can form different tax outcomes. Companies can make reasonable choices based on their own circumstances. Enterprises can transfer capital reserves into share capital. The same place as dividend distribution is that shareholders obtain wealth, but the share capital obtained by shareholders is not personal income, which reduces the tax burden of shareholders [16]. Shareholders can sell shares of companies in the growth period to obtain capital gains. China collects personal income tax on dividends and dividends from individual investment, while capital gains on individual stock transfers are deferred. Shareholders can pay less taxes and obtain the largest shareholder wealth. When tax 
planning of dividend distribution, financial personnel and company shareholders are required to coordinate and cooperate to achieve the company's financial management objectives.

2) Tax planning for the distribution of time and amount of dividends

According to the tax law, the difference between the use of dividend income and capital gains, tax planning can be carried out by reasonable time and amount of dividend distribution [12]. For example, a high-tech enterprise may not distribute profits to subsidiaries. However, if the parent company intends to transfer the shares of the subsidiary company to the outside, the undistributed profits in the subsidiary will be taxed as the proceeds of the stock transfer, which is unfavorable for high-tech enterprises [17]. The high-tech enterprise shall allocate the profits that have not been distributed in previous year to reduce the tax when pre-assigning the equity of the subsidiary. For the high-tech enterprises, the profits that were not allocated in previous year were distributed to delay the tax payment, which can avoid paying out more income tax when the undistributed profits transfer into capital gains. For the subsidiaries, no distributing profits has played a role in slowing down cash outflows, ensuring the demand for cash flow from production and operation, and meeting the high investment demand of high-tech enterprises.

\section{Risk and Control of Tax Planning for High-Tech Enterprises}

\subsection{The Main Risks of Tax Planning for High-Tech Enterprises}

Tax planning requires to respect the law and be familiar with relevant tax incentives and taxation legal relationships. The main risk faced by enterprises is the control and grasp of the law. It is easy to touch the boundaries of the law and create illegal activities. Especially for high-tech enterprises that enjoy many preferential policies [18]. They should interpret policies carefully, avoid risks, and plan taxation rationally. This article will analyze the risks of tax planning from the following aspects.

\subsubsection{Policy Risk}

The policy risk mainly comes from the conflict between the planning scheme and the current legal provisions. This situation often leads to the company taking legal responsibility and has a greater impact on the enterprise. Tax planners should have a better understanding of the legal policy to avoid risks. The specific risks include the following two types.

1) Tax policy understanding the risks caused by deviations, tax planning is a difficult and technically strong business, involving economics, accounting, law, political analysis and knowledge about many other fields, and the requirements for planners are extremely high. Planners and tax law enforcement personnel can create risks due to limited knowledge. Tax planners should maintain good communication with tax law enforcement personnel to understand more relevant laws and policies and prevent risks.

2) Risks arising from tax policy adjustments. As a tool for the state to regulate 
the economy, taxation is always in no change the ground to adapt to the new economic development requirements. The adjustment of tax policy becomes the norm, which makes high-tech enterprises face the risk of violating the law, resulting in unnecessary losses and impacts [13].

\subsubsection{Operational Risk}

Markets are volatile and unstable. Companies survived in the market are at risk and challenge. High-tech enterprises are more risky than their own companies because of their own characteristics. They face greater losses. Planners should have a clear understanding of the economic and market environment to develop programs and reduce unnecessary costs.

1) Risks arising from investment decisions. China has many preferential policies for high-tech enterprises investing in the western regions or special economic zones. They provide investors with a convenient investment environment. However, in the western region, enterprises are faced with high operational risks due to imperfect investment environment and product demand. Enterprises in special economic zones face high market competition and monopoly [19]. It is difficult to develop and expand. If the investor does not know enough about himself and the inaccurate analysis of the environment, it will often lead to difficulties. High-tech enterprises should strengthen their understanding of their own capabilities and understanding of the investment environment, so that they can effectively avoid investment risks by operating consciously and rationally.

2) Risks caused by cost. One of the goals of tax planning is to reduce the cost of taxation and strive for post-tax benefits. Enterprises will ignore the cost of tax planning because they pay too much attention to the tax cost reduction caused by tax savings. High-tech enterprises are mainly small and medium-sized enterprises, lacking professional tax planning personnel. They will pay corresponding compensation and expenses when consulting professional planners, which result in planning costs. Many theoretically feasible tax planning schemes may be affected by many factors and fail to lead to fines, which is also a cost factor that high-tech enterprises need to consider.

\subsection{Evasion Plan for Tax Planning Risks of High-Tech Enterprises}

The risk of tax planning is inevitable. It is easy to violate the relevant legal provisions and generate unnecessary expenditures, which will affect the development of enterprises. Enterprises should adopt effective methods to reduce risks and reduce losses.

1) To enhance the awareness of paying taxes according to law, enterprises cannot evade taxes or evade taxes in violation of the law, but should conduct tax planning on a legal basis. Planners can grasp the country's policy trends, grasp the country's tax policy, and scientifically analyze changes in the tax environment to develop scientific and accurate solutions.

2) Improve the quality of tax planners. Tax planning involves kinds of know- 
ledge, so it requires a high level of professionalism for tax planners. Before the tax planning, it should ensure the planners have strong professionalism, and analyze the state of the enterprise comprehensively and objectively, which can achieve the expected goals of tax planning.

3) Pay attention to the integrity of tax planning. When the ways of business is different, the corresponding tax planning schemes are different. The tax planning schemes should be developed for the actual situation of taxpayers. The planners should have a strategic vision. They should base on the whole process of enterprise investment establishment to bankruptcy dissolution to carry out tax planning. The overall tax burden level is the lowest, achieving financial management objectives.

\section{Conclusion}

This paper is based on the research basis of the predecessors. It analyzes the necessity, strategic choice and risk systematically. The contributions of this paper are to strengthen the planning awareness of high-tech enterprises and provide some ideas and methods for planning. This paper first analyzes the concept and characteristics of high-tech enterprises, and then discusses the concept of tax planning from different directions. It also points out the current situation of high-tech enterprise tax planning, the lack of integrity, divergence and diversity, and the need to carry out tax planning. According to the concept of tax planning, the main part of this paper focuses on the strategic choice of tax planning. From the three aspects of investment, management and financing, the tax planning scheme is listed in the form of case. The scheme involves many aspects of business management. Large taxes provide planning ideas for high-tech enterprises. The form of case analysis makes planning ideas more intuitive and convincing. Tax risk income planning cannot be avoided. The article finally points out the major sources of risk and risk classification, and gives the relevant methods to reduce risk. There are many disciplines involved in tax planning, such as accounting, tax law, enterprise management, and administration. At the same time, it is necessary to communicate well with the tax bureau and coordinate various economic activities with related parties. It is necessary to practice and plan for knowledge. The requirements of the enterprise's ability level are high, so the planning of the plan is difficult. The author's academic level is limited. There are many shortcomings in the research, which need to be improved and gradually deepened in the future theoretical research and practice.

\section{Conflicts of Interest}

The author declares no conflicts of interest regarding the publication of this paper.

\section{References}

[1] Tang, T. and Tang, X. (1994) Tax Planning. China Financial and Economic Pub- 
lishing House, Beijing, 12-20.

[2] Gai, D. (2015) Tax Planning Theory and Practice. Dongbei University of Finance and Economics Press, Dalian, 45-65.

[3] Tong, S. (2012) Research on Tax Planning of High-Tech Enterprises Based on Financial Management Perspective. Master's Thesis, Southwestern University of Finance and Economics, Chengdu, 11-14.

[4] Jiang, Z. (2015) Research on Tax Planning of High-tech Enterprises. Master's Thesis, Shenyang University of Technology, Shenyang, 10-16.

[5] Bai, S. (2010) Research on Tax Planning of High-Tech Enterprises in China. Master's Thesis, Taiyuan University of Technology, Taiyuan, 23-30.

[6] Tian, Z. and Ding, H. (2009) Tax Planning for High-Tech Enterprises under the New Tax System. Northern Economy and Trade, No. 7, 2-3.

[7] Wu, Y. (2008) Research on Tax Planning of High-Tech Enterprises. Master's Thesis, Xiamen University, Xiamen, 5-8.

[8] Lu, S. (2009) Research on Tax Planning of High-tech Enterprises in China. Master's Thesis, Shandong University, Jinan, 2-15.

[9] Ling, J.D. (2008) Tax Planning for High-Tech Enterprises under the New Corporate Income Tax Law. China High-Tech Enterprises, 24, 2-17.

[10] Gai, D. (2001) Tax Accounting and Tax Planning. Northeast Finance University Press People, Dalian, 38-52.

[11] Cao, L. (2005) Research on Tax Risk Management and Prevention of Financial Industry after "Changing Reform". Modern Business and Industry, 19, 1 -2.

[12] Yan, H. (2014) Optimization Design of Tax Planning for High-Tech Enterprises. Master's Thesis, Capital University of Economics and Business, Beijing, 4-10.

[13] Tian, S.D. (2008) Thinking about Planning the Key Points of the High-Tech Corporate Tax. Contemporary Economy, 10, 6-15.

[14] Wang, L.J. (2009) Research on Tax Planning of High-Tech Enterprises. Master's Thesis, Beijing Jiaotong University, Beijing, 7-13.

[15] Zhou, H. (2013) Research on Tax Planning of High-tech Enterprise Income Tax. China Business, 10, 5-9.

[16] Yang, Y. (2015) High-Tech Enterprise Income Tax Planning. Business, 8, 3-4.

[17] Chen, X., Cheng, Q. and Lo, A.K. (2013) Accounting Restatements and External Financing Choices. Contemporary Accounting Research, 30, 50-79. https://doi.org/10.1111/j.1911-3846.2012.01171.x

[18] Ma, C., Zhang, J. and Yang, W. (2016) The Effect of Financial Restatement on Auditor Dismissal. Accounting Research, 54, 79-86.

[19] Chakravarthy, J., Haan, E. and Rajgopal, S. (2014) Reputation Repair after a Serious Restatement. The Accounting Review, 89, 29-36. https://doi.org/10.2308/accr-50716 